УДК 378.14:37.02

\title{
ВПРОВАДЖЕННЯ СУЧАСНИХ ТЕХНОЛОГІЙ В ПРОЦЕС НАВЧАННЯ
}

\author{
Т. В. Чорненька
}

Горлівський медичний коледж

у статті висвітлено поняття та етапи розвитку педагогічної технології, необхідність їх застосування в сучасній системі освіти з метою її реформування і модернізації.

\section{INTRODUCTION OF MODERN TECHNOLOGIES IN THE LEARNING PROCESS}

\section{T. V. Chornenka}

Horlivka Medical College

The article reflects the concepts and stages of development of pedagogical technologies, the need for their use in the modern education system with a view of its reform and modernset.

Вступ. Реформування сучасної освіти України з метою інтеграції в світовий освітній простір передбачає розробку та впровадження інноваційних систем і технологій навчання. Прискорення науково-технічного і соціального прогресу неминуче впливає на побудову освітньої системи. Традиційні педагогічні засоби не забезпечують необхідний рівень освіти. Невідповідність темпів розвитку і характеру соціальних і педагогічних процесів призводить до виникнення кризових явищ у педагогіці. Подолання цих явищ із метою забезпечення високого рівня освіти, гармонійного розвитку людини значною мірою залежить від результативності впровадження інноваційних технологій в процес навчання. Рівень реалізації технологічного підходу визначає конкурентоспроможність та престиж навчального закладу.

Основна частина. Завданнями реформування освітньої системи є виховання освіченої, творчої особистості та формування її фізичного та морального здоров'я. Актуальним стало питання переходу від авторитарної педагогіки до гуманістичного розвитку особистості, від накопичення знань - до вміння оперувати знаннями, від “одноразової» освіти - до безперервної, від поточної організації навчання - до індивідуальної. Згідно з Національною доктриною розвитку освіти України у XXI сторіччі, головна

(c) Т. В. Чорненька, 2015 мета української системи освіти - створення умов для розвитку і самореалізації кожної особистості як громадянина, формування поколінь, здатних навчатися впродовж життя, формування й розвиток цінностей громадського суспільства [1]. Сучасний етап педагогічної практики - перехід від пояснювальноінформаційних технологій до діяльнісно-розвивальних та особистісно-орієнтованих, що створює умови для вдосконалення процесу загальної підготовки. Слово «інновація» має латинське походження і означає введення нового, зміну, оновлення. Поняття «інновація» було введено в наукових дослідженнях ще y XIX cт. і означало проникнення елементів однієї культури в іншу. Поніманська Т. розглядає інновацію як процес створення і використання нових практичних засобів. За її визначенням: «Інновації в системі освіти - це процеси створення й освоєння педагогічних нововведень» [2]. За визначенням В. Слободчикова: «нновація - кінцевий результат творчої діяльності у вигляді нової чи удосконаленої продукції, нового чи удосконаленого технологічного процесу» [3].

Отже, педагогічні інновації - це назва нового педагогічного продукту, що впроваджується у навчальний процес.

Термін «технологія» має походження від двох грецьких слів - techne (мистецтво, майстерність, уміння) та logos (наука, вчення). Терміни «педагогічна технологія», «освітні технології», «технологія в освіті» 
поширились у 50 роках XX сторіччя у зв'язку із впровадженням нових засобів навчання і отримали безліч формулювань залежно від точки зору авторів на структуру та складові освітнього процесу.

Завизначенням В. Гузєєва: «Педагогічна технологія» являє собою сукупність педагогічних прийомів, що забезпечують досягнення педагогічних цілей [4]. Селевко Г. формулює поняття «педагогічної технології» як систему функціонування всіх компонентів педагогічного процесу, що побудована на науковій основі, запрограмована в часі й просторі та приводить до намічених результатів [5].

3 огляду на це, педагогічна технологія - це системний метод викладання та засвоєння знань, спрямований на досягнення поставленої мети, що дає позитивні зміни у традиційному педагогічному процесі шляхом його модернізації.

Елементи технологічного підходу можна знайти в працях таких видатних вітчизняних та іноземних педагогів, як А. С. Макаренко, В. О. Сухомлинський, А. Дистервег та інші.

Умовно розвиток педагогічної технології у світовому просторі можна поділити на три етапи, кожен 3 яких характеризується перевагою тих чи інших тенденцій.

Першийетап (40 - середина 50 рр.)характеризується появою в навчальних закладах різноманітних технічних засобів подачі інформації (магнітофонів, програвачів, проекторів, телевізорів тощо), об'єднаних поняттям «аудіовізуальні засоби». В основному вони були призначені для побутової мети.

На другому етапі (середина 50 - 60 рр.) виникає програмоване навчання. Розробляються аудіовізуальні засоби, спеціально призначені для навчальної мети: електронні класи, засоби зворотнього зв'язку, лінгафонні кабінети, тренажери. На зміну терміну «технологія навчання» прийшов термін «технологія освіти», який означав науковий опис навчального процесу. У 1967 р. в Англії було створено Національну раду з педагогічної технології, у США - Інститут педагогічної технології.

На третьому етапі (70 роки) розширюється база педагогічної технології. До аудіовізуальних засобів і програмованого навчання додаються інформатика, системний аналіз, теорія телекомунікацій, педагогічні науки (психологія навчання, теорія керування пізнавальною діяльністю, організація навчального процесу, наукова організація педагогічної праці). Змінюється методична основа, починається підготовка професіональних педагогів-технологів. 3'являються нові, більш сучасні аудіовізуальні засоби (відеомагнітофон, поліекран, електронна дошка, рейкова система кріплення схем, синхронізатори звуку і зображення тощо). В основу технологій навчального процесу покладають системний підхід.

у 80 роках почався новий етап розвитку поняття «педагогічна технологія». Він характеризується зростанням кількості та якості педагогічних програм, використанням сучасних засобів передачі інформації, інформатизацією суспільства.

Інформатизація суспільства - глобальний соціальний процес, в основі якого лежить збирання, накопичення, оброблення, зберігання, передача та використання інформації. Інформація освіти спрямована на формування та розвиток інтелектуального потенціалу нації.

Інтерактивність, інтенсифікація процесу навчання, зворотний зв'язок - помітні переваги комп'ютерних технологій, котрі зумовили необхідність їх використання у галузях, які пов'язані з освітою та професійною підготовкою. Впровадження комп'ютерної техніки в сферу освіти стало початком революційного перетворення традиційних методів і технологій навчання та всієї галузі освіти, дало змогу підвищити якість освітніх технологій.

Висновки. Забезпечення якісної підготовки спеціалістів на рівні міжнародних стандартів найважливіше стратегічне завдання української освітньої системи. Вирішити це завдання можливо лише за умови впровадження інноваційних педагогічних технологій, тобто новітніх форм і методів викладання, останніх досягнень технічного прогресу. Використання інноваційних технологій дозволяє надавати велику за обсягом інформацію у більшому, ніж традиційні джерела, об'ємі, навчитися правильно користуватися цією інформацією дає усвідомлення учнями своєї індивідуальності, утверджує самоактуалізацію та саморозвиток особистості вчителя та учня [6].

Сучасні умови вимагають поряд із традиційними формами навчання застосовувати і нетрадиційні, інноваційні технології, які взаємодоповнюють одні одних, оскільки вони на належній матеріальній базі вищих навчальних закладів можуть забезпечити високу якість підготовки спеціалістів. 


\section{ЛITEPATУРA}

1. Національна доктрина розвитку освіти України у XXI столітті. - К. : Райдуга, 2001. -16 с.

2. Поніманська Т. І. Готовність до педагогічних інновацій - показник гуманного мислення педагога / Т. І. Поніманська // Інновації в сучасному педагогічному процесі: теорія та практика : зб. статей за матеріалами Всеукр. наук.-практ. конф., 21-22 груд. 1999 р. - Луганськ, 1999. - С. 133-136.

3. Слободчиков В. И. Проблемы становления и развития инновационного образования / В. И. Слободчиков // Инновации в образовании. - 2003. - № 2. - С. 4-18.
4.ГузеевВ.В. Основа авторской технологии/В.В. Гузеев// Народное образование. - 1997. - № 9. - С. 33-40.

5. Селевко Г. К. Энциклопедия образовательных технологий : в 2 т. / Г. К. Селевко. - М. : НИИ школьных технологий, 2006. - Т. 2. - 816 с.

6. Табакова М. І. Використання сучасних методичних та методологічних підходів щодо формування цілісної системи знань та вмінь майбутнього фахівця-медика / М. І. Табакова. - Чернівці, 2007. - С. 94-95.

Отримано 06.11.15 